\title{
IAMJ
}

INTERNATIONAL

AYURVEDIC

MEDICAL JOURNAL

do) $\partial$ (1)

$\underline{\text { Research Article }}$

ISSN: 2320-5091

Impact Factor: 6.719

\section{CLINICAL EFFICACY OF DADRUVIDRAVANA MALAHARA IN THE MANAGEMENT OF DADRU KUSHTA}

\author{
Lakshmi Reshma Kollipara $^{1}$, Ch. Sridurga ${ }^{2}$, K. Satya Prabha1 ${ }^{3}$ \\ ${ }^{1}$ Final year PG Scholar, Department of Rasa Shastra and Baishajya Kalpana, S.V Ayurvedic College, Tirupati, \\ Andhra Pradesh, India \\ ${ }^{2}$ Professor and HOD, Department of Rasa Shastra and Baishajya Kalpana, S.V Ayurvedic College, Tirupati, \\ Andhra Pradesh, India \\ ${ }^{3}$ Professor and HOD, department of Roga Nidana, S.V Ayurvedic College, Tirupati, Andhra Pradesh, India
}

Corresponding Author: reshmagkollipara@gmail.com

https://doi.org/10.46607/iamj07p6012021

(Published online: November 2021)

Open Access

(C) International Ayurvedic Medical Journal, India 2021

Article Received: 06/11/2021 - Peer Reviewed: 24/11/2021 - Accepted for Publication: 26/11/2021

Check for updates

\begin{abstract}
Background: Dadru is a commonly encountered skin disease described in various classical Ayurvedic texts. The cardinal features of Dadru are Kandu, Raga, Pidaka and Utsanna Mandala. This disease can be correlated with Ringworm infection based on the clinical features. Dadruvidravana Malahara is one of the unique formulations mentioned in Rasa Tarangini indicated for the management of Dadru. Aim: This study is aimed to evaluate the efficacy of Dadruvidravana Malahara in the management of Dadru. Materials and Methods: A non-randomized, single-armed, open-labelled clinical trial was conducted in thirty patients having classical symptoms of Dadru, administered with Dadruvidravana Malahara twice a day for 60 days. The assessment was done based on subjective parameters i.e., Kandu, Raga, Pidaka, Visarpana, Utsanna Mandala and objective parameters i.e., number of Mandala, size of Mandala and number of Pidaka. The results were statistically analyzed using the paired $t$-test. Results: Statistically extremely significant relief $(P<0.001)$ was noted in all the subjective and objective parameters. Conclusion: Dadruvidravana Malahara can be considered as an effective formulation in the management of Dadru Kushta.
\end{abstract}

Keywords: Dadru, Dadruvidravana Malahara, Ringworm infection. 


\section{INTRODUCTION}

Skin is the most common organ to get afflicted with diseases in humans. Almost $12.4 \%$, of the total patients that approach treatment to general practitioners, complains of skin-related ailments. Ayurveda classified all the skin diseases under a single heading called Kushta. This ailment was added among the dreadful eight diseases in virtue of its influence on the human body and psychology. Dadru Kushta is one among them. The signs and symptoms of this disease correlate with -common Ringworm infection. Ringworm occurs when a type of fungus called Tinea grows and multiplies on the skin. This Tinea infection alone comprises more than $1 /^{\text {th }}$ of all fungal skin infections that occur in humans. Ringworm can spread easily from one person to another. Uninfected can catch ringworm if he touches someone who has the infection, or if they allegedly come into contact with items contaminated by fungus, such as combs, unwashed clothes, etc.

Ringworm is very tenacious thus long-term medication is required. The antifungal medicaments available in the market have some adverse effects on the human body. Since fungal organisms are Eukaryotic cells that contain most of the same organelles as human cells, the identification of drugs that selectively kill or inhibit fungi but are not toxic to human cells has been highly problematic ${ }^{(1)}$. Antifungal drugs have their side effects. So, there is a need of exploring a safe and effective medicine.

Dadruvidravana Malahara is one such formulation mentioned in Rasa Tarangini Gandhaka Vignaniya Taranga, sloka no: 59-62 claimed to be beneficial in Dadru Kushta.

Dadruvidravana Malahara contains Sikta Taila, Shuddha Gandhaka (Sulphur), Shuddha Tankana (Borax), Laksha Churna, Chakramarda Beeja Churna (Cassia tora Linn) ${ }^{(2)}$.

All the ingredients present in Dadruvidravana Malahara have Katu, Madhura Rasa, Ushna Virya, Katu Vipaka, Kushtaghna, Kandughna, Dadrughna, Krimighna, Tridoshahara and Twakprasadana properties. When combined, these drugs are expected to show their synergistic action against Dadru Kushta.
Hence, to find the efficacy of Dadruvidravana Malahara on Dadru Kushta with respect to Ringworm infection, this drug has been selected.

\section{MATERIALS AND METHODS}

A total of 33 patients having classical symptoms of Dadru attending the OPD of Roga Nidana and Rasa Shastra \& Bhaishajya Kalpana department from Institute hospital, were selected irrespective of sex, caste, religion etc., taking due considerations of inclusion and exclusion criteria. The study was started after approval from the Institutional Ethics Committee (IEC/SVAYC/RS/19/03) dated 25-8-2021. Informed written consent was taken from each patient before starting the treatment.

\section{Inclusion Criteria}

Patients with the classical signs and symptoms of Dadru Kushta viz., Kandu, Raga, Utsanna, Mandala and Pidaika. Patients of 16 to 60 years of age will be included. Patients belonging to either gender will be included.

\section{Exclusion Criteria}

Pregnant women and lactating mothers will be excluded.

\section{Posology}

\section{External Therapy: Dadruvidravana Malahara}

Dose: sufficient quantity

Kala: Twice a day

Duration:60 days

\section{Reason for selecting the topical mode of admin- istration:}

Ringworm infection is caused by fungi that require keratin for growth. These fungi can cause superficial infections of the skin, nails and hair and obtain nutrients from the keratinized material. They cannot penetrate deeper into the living tissue of an immunocompetent host ${ }^{(3)}$. Thus, they are generally restricted to superficial layers of the skin and can be managed even through topical treatment.

Topical application is the application of a drug, containing formulation to the skin or mucous membrane, to treat specific cutaneous disorders or cutaneous manifestations of a generalised disease, with the intent of containing, the pharmacological effect of the 
drug only to the surface or within the layers of skin or mucous membrane ${ }^{(4)}$.

Through the topical application, drug delivery can be restricted only to a specific site, thereby sparing the healthy tissue from getting exposed to the drug.

Even Acharya Charaka advised the same as शरीरावायवोट्थेत्थेषु विसर्पपीडकादिषु I यथादेशं प्रदेहादी शमनं स्यदविशेषतः II (Ca.Ch. 30/294).

For this reason, Dadruvidravana Malahara drug is selected for the management of Dadru Kushta.

The base of the drug Dadruvidravana Malahara is Sikta Taila. Sikta Taila has emollient property. The Taila hydrates and softens the skin. It prevents the escape of water through the skin by forming a protective layer above the lesion.

Hydration of skin increases absorption of the drug. Thus, Sikta Taila might be the ideal base for the preparation of Malahara.

When Bee's wax is combined with borax it exhibits, emulsifying property thereby increasing the binding capacity among the ingredients of the drug.

Fungi are aerobic organisms. They require oxygen for survival. When the oleaginous Malahara is applied over the lesion, it decreases the oxygen supply to the fungi. This also helps in the retardation of fungi.

\section{Statistical analysis}

Statistical test for assessment of the data was performed using the paired $t$-test using GraphPad Prism software, USA.

Diet and Regimen:

Pathya: Patola, Takra, Shigru, Nimba, Karavellaka, Lashuna, Snana.

Apathya: The patient was advised to avoid brinjal, fish, milk, protein, sweets, non-vegetarian and other oily, spicy foods.

Instructions: Maintain proper cleanliness, wash cloths in hot water separately, avoid physical closeness to prevent transmission of infection, not to scratch due to itching sensation and avoid sharing combs, blankets, etc with others.
Method of Preparation of Dadruvidravana Mala-

hara: The pharmaceutical procedures adopted in this study are Shodhana, Churna nirmana, Mardana and the preparation of Dadruvidravana Malahara.

Gandhaka Shodhana was done by subjecting Gandhaka to Dhalana in Go Ksheera 7 times ${ }^{(5)}$. Tankana Shodhana was done by Nirjalikarana method ${ }^{(6)}$. Laksha and Chakramarda Beeja were made into fine powder. Sikta Taila was prepared, to those fine powders of Shudda Gandhaka, Shudda Tankana, Laksha Churna and Chakramarda Beeja Churna were added and mixed well to form a homogenous mixture of Dadruvidravana Malahara.

\section{Criteria for Assessment:}

General Observation: Various demographic parameters viz. Age, Marital Status, Religion, Nature of work etc. along with specific features of Prakriti, Satva, Samhanana etc. were analyzed in the present clinical trial.

Subjective Assessment: Criteria of assessment were kept based on relief in the sign and symptoms of $\mathrm{Da}$ dru Kushta before and after the treatment. For this purpose, cardinal signs and symptoms were given scores.

Kandu

Grade

No itching

Occasional itching 1

Tolerate itching 2

Severe itching 3

Raga

Normal skin color

Grade

Faint color

Blanching + red color 2

Red color 3

Utsanna

Grade

No elevation

0

Elevation can be felt 1

Elevation in all lesions but soft 2

Elevation in all lesions but hard 3

- Visarpana

Grade

Avisarpana

0

Adha to urdhva/ Urdhva to adha 1

Shaka to Madhyama/Madhyama to Shaka 2

Whole body
0

1

rade

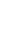

rade

1
2
3




\section{Objective Assessment:}

$\begin{array}{ll}\text { 1. No. of Mandala } & \text { Grade } \\ \text { No Mandala } & 0 \\ 1 \text { to } 3 \text { Mandala } & 1 \\ 4 \text { to } 6 \text { Mandala } & 2 \\ \text { More than 6 Mandala } & 3 \\ \text { 2. Size of Mandala } & \text { Grade } \\ \text { No lesions } & 0 \\ \text { Less than } 5 \mathrm{~cm} & 1 \\ 5 \text { to } 10 \mathrm{~cm} & 2 \\ \text { More than } 10 \mathrm{~cm} & 3 \\ \text { 3. No. Of Pidaka } & \text { Grade } \\ \text { No Pidaka } & 0 \\ \text { 1 to } 3 \text { Pidaka } & 1 \\ 4 \text { to 6 Pidaka } & 2 \\ \text { More than } 6 \text { Pidaka } & 3\end{array}$

\section{Criteria for Overall Effect of Therapy}

The total effect of the therapy was assessed considering the following criteria - Complete remission: $76 \%-100 \%$, Markedly improved: $51 \%-75 \%$, Mild improvement: $26 \%-50 \%$, No

improvement: $<25 \%$.

\section{Statistical Evaluation of Results}

The obtained information was analyzed statistically in terms of the mean score $(\mathrm{x})$, standard deviation, standard error. Paired $t$-test was conducted at the level of $0.05,0.01$ and 0.001 of $P$ levels. The results were interpreted as follows - Insignificant: $P>0.05$, Significant: $P<0.05$, Highly significant: $P<0.01$, Extremely significant: $P<0.001$

\section{Observations}

A total of 36 patients were registered among them 30 patients had completed the treatment and 6 patients were dropped out from the course of treatment due to various reasons.

In the present study, a maximum number of patients i.e., $10(33.33 \%)$ were between $16-25$ years age group, followed by 8 patients $(26.66 \%)$ between $26-$ 35 years age group, 5 patients $(16.66 \%)$ between $36-$ 45 years age group, 5 patients $(16.66 \%)$ between 46 to 55 years age group and 2 patients $(6.66 \%)$ were between 55-60 years age group. Eighteen $(60.00 \%)$ were male and 12 patients $(40.00 \%)$ were female, a maximum number of patients i.e., 17 (56.66\%) were
Hindus and 20 patients were married. 17 (56.66\%) were from Rural areas, while 13 patients $(43.33 \%)$ were from Urban areas. The majority of patients, i.e., $20(67 \%)$, were educated and $12(40 \%)$ patients belonged to the middle class. Total $13(43.33 \%)$ patients were students whereas $17(56.67 \%)$ patients were engaged with sedentary work and other works. A maximum number of patients i.e., 27 (90.00\%) were consuming a mixed diet; $18(60.00 \%)$ were having Mandagni, 8 patients $(26.6 \%)$ were having $\mathrm{Vi}$ shamagni, and 4 patients $(13.3 \%)$ were having $\mathrm{Sa}$ magni. $20(66.6 \%)$ had disturbed sleep and 10 patients $(33.3 \%)$ had normal sleep. a maximum number of patients i.e., $12(40.00 \%)$ patients didn't have any addiction, 6 patients $(20.00 \%)$ had a habit of drinking tea, 6 patients $(20.00 \%)$ had a habit of drinking alcohol, 3patients $(10.00 \%)$ had a habit of chewing tobacco and 3 patients (10\%) were smokers. 18 (60.00\%) were of Vata-Kapha Prakruti, 7 patients (23.3\%) were of Pitta-Kapha Prakruti, 5 patients (16.6\%) were of Vata-Pitta Prakruti. A maximum number of patients i.e., $18(60 \%)$ had Madhyama Kostha, 8 patients (26.6\%) had Mridu Kostha, and 4 patients (13.3\%) had Krura Kostha. Four patients $(13.33 \%)$ had lesions over the abdomen, 5 patients $(16.66 \%)$ had lesions on the upper limb, 3 patients $(10 \%)$ on the head, 24 patients $(80 \%)$ had lesions on the inguinal area and lower limbs. Kandu and Mandala were observed in all patients i.e. $100 \%$ followed by Utsanna in 28 patients $(93.33 \%)$ and Rakta Varna in 20 patients $(66.66 \%)$. A maximum number of patients i.e., 10 (33.33\%) patients had chronicity of 3 to 6 months, 8 patients $(26.66 \%)$ had chronicity of 1 to 3 months, 6 patients $(20.00 \%)$ had chronicity less than 1 month, 6 patients $(20 \%)$ had chronicity of greater than 6 months. $22(73.00 \%)$ had multiple lesions while 8 patients $(27.00 \%)$ had a single lesion. $20(66.66 \%)$ patients complained of spread while 10 patients $(33.33 \%)$ had no spread.

\section{RESULTS}

Effect of Dadruvidravana Malahara on Dadru Kushta in thirty patients

Statistically Extremely significant relief $(\mathrm{P}<0.0001)$ was found in Kandu, Raga, Utsanna Visarpan, num- 
ber of Mandala, size of Mandala and number of Pidaka.

\section{Overall assessment of the therapeutic effect}

The therapy had shown marked improvement in $57 \%$ of patients, moderate improvement in $27 \%$ of patients, and mild improvement was noticed in $6.6 \%$ of patients.

\section{DISCUSSION}

\section{EFFECT ON SUBJECTIVE PARAMETERS:}

\section{Effect on Kandu:}

All the 30 patients were having Kandu with the mean initial score of 2.40 which was reduced to 0.27 after the treatment. The improvement is statistically extremely significant $(\mathrm{P}<0.0001)$. Kandu is mainly due to Kapha dosha. The extremely significant relief in Kandu may be due to the following reasons:

- The Katu Rasa of Chakramarda, Gandhaka and Tankana pacify Kapha Dosha.

- Laghu, Ruksha guna and Ushna Veerya of Chakramarda pacify Kapha Dosha.

- Ushna Veerya and Katu Vipaka of Gandhaka pacify Kapha Dosha.

- Ruksha, Tikshna and Ushna Guna, Ushna Veerya and Katu Vipaka of Tankana pacify Kapha Dosha.

- Kashaya, Tikta Rasa of Laksha pacify Kapha Dosha.

- Kandughna property of Gandhaka. Because of its Prabhava, Gandhaka pacifies Kandu.

Effect on Raaga: All the 30 patients were having Raaga with the mean initial score of 2.07 which was reduced to 0.43 after the treatment. The improvement is statistically extremely significant $(\mathrm{P}<0.0001)$. Raaga is mainly due to Pitta Dosha. The extremely significant relief in Raaga may be due to the following reasons:

- Kashaya Tikta Rasa and Pitta Shamaka Guna of Laksha pacify Pitta Dosha.

- Amapachana Guna of Gandhaka.

- Sheeta, Picchala Guna, Twak Prasadana Guna of Sikta Taila pacify Pitta Dosha.

Effect on Utsanna: Among 30 patients, 28 patients were having Utsanna with the mean initial score of
2.60 which was reduced to 0.80 after the treatment. Statistically, this improvement is extremely significant $(\mathrm{P}<0.0001)$. Utsanna is mainly due to Kapha and Pitta Dosha. The extremely significant relief in Utsanna may be due to the following reasons:

- The Katu Rasa has, Lekhana and Vranavasadaya Guna. It removes the excess growth. The Katu Rasa of Chakramarda, Gandhaka and Tankana decreases Utsanna.

- Laghu, Ruksha Guna and Ushna Veerya of Chakramarda pacify Kapha Dosha.

- Ushna Veerya and Katu Vipaka of Gandhaka pacify Kapha Dosha.

- Ruksha, Tikshna and Ushna Guna, Ushna Veerya and Katu Vipaka of Tankana pacify Kapha Dosha.

- Kashaya, Tikta Rasa of Laksha pacify Kapha Dosha.

- Kashaya Tikta Rasa and Pitta Shamaka Guna of Laksha; Sheeta, Picchala Guna, Twak Prasadana Guna of Sikta Taila pacify Pitta Dosha.

Effect on Visarpana: Among 30 patients, 20 patients were having Visarpana with the mean initial score of 1.60 which was reduced to 0.00 after the treatment. Statistically, this improvement is extremely significant $(\mathrm{P}<0.0001)$. Visarpana is mainly due to Dushita Rakta and Pitta Dosha. The extremely significant relief in Visarpana may be due to the following reasons:

Amapachana Guna of Gandhaka removes the Aama Dosha in Dushita Rakta.

Pittashamaka Guna of Laksha pacifies Pitta thereby normalizing the Dushita Rakta.

Even though the organism colonizes only in the dead keratinized tissue, an inflammatory response was elicited due to activation of T-cell mediated immunity to fungal metabolites. Histamines were released and caused itching. Scratching may temporarily relieve itching by interrupting the rhythm of nerve impulses or by inflicting transitory damage to the nerves.

Scratching is one of the main reasons for the spreading of the disease. While scratching, the organism will get carried to distant places. When itching gets 
reduced, the patient automatically scratches less thereby, decreasing the disease spread ${ }^{(7)}$.

By virtue of its ingredients, Dadruvidravana Malahara showed maximum relief in Kandu. Since Kandu was reduced, the patient might have stopped scratching. This might be the reason for maximum relief in Visarpana.

\section{Effect on Objective parameters:}

All the 30 patients were having different Numbers of Mandala with a mean initial score of 2.20 which was reduced to 0.93 after the treatment. The improvement is statistically extremely significant $(\mathrm{P}<0.0001)$. Mandala is mainly due to Kapha dosha. The extremely significant relief in the Number of Mandala may be due to Kaphapittghna, Kushtaghna, Dadrughna and Krimighna properties of the drug.

All the 30 patients were having different Sizes of Mandala, with a mean initial score of 2.13 which was reduced to 0.70 after the treatment. The improvement is statistically extremely significant $(\mathrm{P}<0.0001)$. The extremely significant relief in size of Mandala may be due to Kaphapittghna, Kushtaghna, Dadrughna and Krimighna properties of the drug.

Among 30 patients, 23 patients were having Pidaka with the mean initial score of 1.33 which was reduced to 0.40 after the treatment. Statistically, this improvement is extremely significant $(\mathrm{P}<0.0001)$. Pidaka is mainly due to Pitta dosha and Rakta Dushti. The extremely significant relief in the Number of Pidaka may be due to Pittaghna, Kushtaghna, Raktadoshahara, Twakprasadana, properties of the drug. Probable mode of action of drug:

Acharya Charaka has mentioned that the drugs show their actions due to their five properties viz. Rasa, Guna, Virya, Vipaka and Karma. The action of a compound formulation is decided by the action of a major ingredient or by the synergistic action of all the ingredients. The actions of ingredients of Dadruvidravana Malahara are as follows:

Table 1: Showing Rasa Panchaka of Dadruvidravana Malahara

\begin{tabular}{|c|c|c|c|c|c|c|}
\hline Ingredient & Rasa & Guna & Virya & Vipaka & Karma & Biological Action \\
\hline Sikta Taila & Madhura Kashaya, & $\begin{array}{l}\text { Sheeta, } \\
\text { Snigdha }\end{array}$ & Sheeta & Madhura & $\begin{array}{l}\text { Vrana Ropana, } \\
\text { Kushtaghna, } \\
\text { Kandughna, } \\
\text { Twachya }\end{array}$ & - \\
\hline Gandhaka & $\begin{array}{l}\text { Madhura } \\
\text { Katu }\end{array}$ & $\begin{array}{l}\text { Laghu, } \\
\text { Ruksha, }\end{array}$ & Ushna & Katu & $\begin{array}{l}\text { Pachana, } \\
\text { Kushtaghna, } \\
\text { Krimighna, } \\
\text { Kandughna, } \\
\text { Dadrughna }\end{array}$ & Antioxidant (8) \\
\hline Tankana & Katu & $\begin{array}{l}\text { Ruksha, } \\
\text { Tikshna, } \\
\text { Ushna }\end{array}$ & Ushna & Katu & $\begin{array}{l}\text { Deepana, Balya, } \\
\text { Shoolaghna }\end{array}$ & $\begin{array}{l}\text { Anti-septic, } \\
\text { Astringent, } \\
\text { Diuretic, Refrigerant, } \\
\text { Lithotriptic }^{(9)} \text {. }\end{array}$ \\
\hline Laksha & $\begin{array}{l}\text { Kashaya } \\
\text { Tikta }\end{array}$ & $\begin{array}{l}\text { Laghu } \\
\text { Snigdha, }\end{array}$ & Anushna & - & $\begin{array}{l}\text { Kushtaghna, } \\
\text { Krimighna, } \\
\text { Raktadoshahara, } \\
\text { Vranaropana, } \\
\text { Varnya }\end{array}$ & - \\
\hline Chakramarda & $\begin{array}{l}\text { Katu } \\
\text { Madhura }\end{array}$ & $\begin{array}{l}\text { Ruksha, } \\
\text { Laghu }\end{array}$ & Ushna & Katu & $\begin{array}{l}\text { Kushtaghna, } \\
\text { Krimighna, } \\
\text { Kandughna, } \\
\text { Dadrughna, } \\
\text { Vishaghna }\end{array}$ & $\begin{array}{l}\text { Anti-Bacterial, } \\
\text { Anti-Fungal }^{(10)}\end{array}$ \\
\hline
\end{tabular}


Based on this, the probable Rasa Panchaka for Dadruvidravana Malahara is

Rasa: Katu, Madhura

Guna: Laghu Ruksha

Virya: Ushna

Vipaka: Katu

Karma: Tridoshahara, Pachana, Kushtaghna, Krimighna, Kandughna, Dadrughna, Vishaghna, Vranaropaka, Twakprasadana.

Thus, Dadruvidravana Malahara works by its

- Hetu prathyanikatva i.e. - by the specific Tridoshaghna properties of ingredients the drug might be acting against the hetu of Dadru (Kapha Pitta Pradhana as per Charaka and Tridosha as per Susrutha).

- Vyadhi prathyanikatva i.e. - by the Kushtaghna, Krimighna, Dadrughna Twakdoshahara properties of ingredients, maybe acting against Dadru Kushta.

\section{Probable Mode of Action According to Modern} View:

Sulphur has Keratolytic and Anti-Fungal activity. Due to its Keratolytic Activity, it destroys the infected keratocytes along with the fungi.

Borax has Antiseptic properties. In a study, it was found that Borax can be diffused only into inflammated cells (because of disruption of the permeability of the cell membrane due to inflammation), it cannot penetrate normal healthy cell ${ }^{\mathrm{s}}{ }^{(11)}$. The addition of borax to a Sulphur compound might make the compound penetrate only the affected keratocytes thereby, sparing the healthy keratocytes.

Chrysophanic acid-9-anthrone, an antifungal principle isolated from the seeds of Chakramarda was reported to be fungicidal against Trichophyton rubrum, T. mentagrophytes, Microsporum canis M. gypseum and Geotrichum candidum ${ }^{(12)}$.

Dermatophytes might cause post-inflammatory hyperpigmentation due to unknown reasons, thereby leaving hyperpigmented patches ${ }^{(13)}$. These hyperpigmented patches can be normalized by the use of Laksha (which is having Varnya and Twak Prasadana Guna $)^{(14)}$ in the formulation.

Acharya Susrutha advised the use of Chakramarda, as Lepa for Pandu Karma of Vrana ${ }^{(15)}$. Through this, we can infer the melanolytic activity of Chakramar$d a$. This property of Chakramarda might help in reducing the hyperpigmentation of the dermatophyte's lesions.

\section{CONCLUSION}

Dadruvidravana Malahara has provided significant results on the parameters of Dadru. Based on the present clinical study, it can be concluded that Dadruvidravana Malahara is an efficacious formulation for the management of Dadru. No adverse effects were reported during the entire study period. The present clinical trial was carried out on a limited number of patients. Hence, an extended study with more clinical parameters and on a large number of patients can be considered to find the effect treatment prevention of recurrence.

\section{REFERENCES}

1. Chaminda. J et al., Antifungal Drug Discovery: New Theories and New Therapies. 2016,7:728.

2. Kashinath Shastrina, Rasa Tarangini by Motilal Varanasi Das Prakashana, Reprint 2014, Chapter8/59-62. Pg. No. 87.

3. https://en.wikipedia.org/wiki/Dermatophyte

4. https://www.slideshare.net/doctormansij/topical-routemansij

5. Siddhi Nandana Mishra, Rasa Ratna Samuchchayah by Chaukhambha Orientalia, reprint2017, Chapter 3/20-22. Pg.No. 64.

6. Kashinath Shastrina, Rasa Tarangini by Motilal Varanasi Das Prakashana, Reprint 2014, Chapter 13/77-78, Pg. No 315

7. Dr.P.S. Byadgi, A Textbook of Kayacikitsa Vol III by Chaukambha Publications, First Edition 2013, Page no. 578

8. www.ncbi.nlm.nih.gov/pubmed/19548119, the antioxidant activity of sulfur and selenium.

9. Tarak R. et al., Invitro Antimicrobial activity of Tankan; EJBPS; 2015; 2(7); 210-213.

10. Viniti Tiwari, Chakramard (Cassia tora Linn.): Natural Drug for Skin Disorder, 2019, 8(3), 246-262.

11. https://www.healthline.com/health/is-borax-safe\#safeuses

12. T K Acharya, et al., Isolation of chrysophanic acid-9anthrone, the major antifungal principle of Cassia tora, May-Jun 1975;38(3):218-20 
13. https://www.verywellhealth.com/ringworm-signs-

symptoms-complications-4163126

14. Dr. Bulusu Sitaram, Bhavaprakasha Nighantu by Chaukambha Orientalia, Reprint 2015, Haritakyadi Varga sloka no.193-195, Pg. No 179

15. K.R. Srikanth Murthy, Susruta Samhita by Chaukhambha Orientalia, Reprint 2010, Chikitsa Sthana, Chapter 1/97-98. Pg.No. 22.

\section{Source of Support: Nil \\ Conflict of Interest: None Declared}

How to cite this URL: Lakshmi Reshma Kollipara et al: Clinical Efficacy Of Dadruvidravana Malahara In The Management Of Dadru Kushta. International Ayurvedic Medical Journal \{online\} 2021 \{cited November 2021\} Available

from:

http://www.iamj.in/posts/images/upload/3200_3207.pdf 